\title{
Efforts To Improve Regional Original Income of Medan City Through Hotel Taxes
}

\author{
Deasy Arisandy Aruan, Dianty Putri Purba \\ Prima Indonesia University \\ E-mail address_deasy.aruan@gmail.com, Email address puputpurba27@yahoo.com
}

\begin{abstract}
The purpose of this research is to find out how the contribution of Hotel Taxes in increasing the Regional Original Income of Medan City and what are the efforts in increasing the hotel tax. Sources of data used in this research are secondary data, namely in the form of targets and realization of hotel tax revenue and realization of local revenue Medan City from 2016 to 2018. The data analysis technique used in this study is to use descriptive analysis. Hotel Tax to Local Own Revenue is to compare the actual value of Hotel Tax with the realization of Local Own Revenue in Medan City. The results show that in 2016-2018, the contribution of Hotel Tax in the city of Medan increased every year. In contrast to the contribution, the value of the realization of Regional Original Income tends to fluctuate because, in 2016-2017, it increased, while in 2018, the realization value decreased.
\end{abstract}

Keywords: Hotel Taxes, Local Own Revenue

\section{INTRODUCTION}

This is an open access article under the CC-BY-NC license.

Based on Law Number 33 of 2004, the definition of Regional Original Revenue is revenue obtained by the region, which is collected based on regional regulations in accordance with statutory regulations. Local governments are given the authority to maximize Regional Original Income. One of the efforts to increase local revenue is to increase the effectiveness and contribution of local revenue sources such as local taxes, local retribution, the share of BUMD profits, revenue from government agencies, and other revenues. The proceeds from the original regional income are used for the needs of the people, such as building roads, local government hospitals, bridges, opening new jobs, and so on.

One of the contributors to Local Own Revenue is hotel tax. Hotels needed people to travel longer by staying overnight. However, nowadays, people are no longer traveling only in the Berastagi or Parapat areas, but also in Medan City. Since 2018, a staycation trend has emerged, where people travel to hotels in urban areas. That way, it doesn't take much time to get to a tourist destination. This staycation trend is also favored by millennials because by staying at Instagramable hotels; they can have stock photos and videos to upload on their social media. 
Proceeding on Japan International Business and Management Research Conference (JIBM),

Vol. 1(1), 99-104

Efforts to Improve Regional Original Income of Medan City Through Hotel Taxes

Deasy Arisandy Aruan, Dianty Putri Purba

Table 1.1 Realization of Hotel Tax and Local Own Revenue in Medan City

\begin{tabular}{cccc}
\hline Year & Realization of Hotel Tax & $\begin{array}{c}\text { Realization of Local Own } \\
\text { Revenue }\end{array}$ & \% contribution \\
\hline 2016 & 95.882 .427 .290 & 1.535 .309 .574 .015 & 6,24 \\
2017 & 109.115 .442 .280 & 1.739 .756 .922 .634 & 6,27 \\
2018 & 119.664 .695 .854 & 1.636 .204 .514 .684 & 7,31 \\
\hline
\end{tabular}

If seen from the table above, the hotel tax realization value continues to increase, but the realization of Regional Original Revenue tends to fluctuate because it has increased in 2016-2017 and decreased in 2018. However, the contribution rate increases every year. However, if it is related to the criteria of the 1991 Research and Development Team of the Department of Home Affairs, Faculty of Social and Political Sciences, the contribution of hotel taxes to Regional Original Income is very insufficient. Therefore, researchers are interested in conducting research to determine and analyze how and how to increase hotel taxes so that there is an increase in Regional Original Income in the city of Medan, thus taking the title "Efforts to Increase Regional Original Income in Medan City through Hotel Taxes.

\section{LITERATURE REVIEW}

\section{II.1 Regional Original Revenue}

The definition of Regional Original Revenue, according to Law Number 33 of 2004, is the revenue collected by the Regional Government based on regional regulations that are adjusted to the laws and regulations. Regional Original Income aims to give authority to the Regional Government to fund the implementation of regional autonomy, which is linked to regional potential as a form of decentralization. Sources of Regional Original Income include:
a. Local Taxes
b. Regional Retribution,
c. The results of processing separated regional assets, and
d. Other legal Regional Original Revenue.

\section{II.2 Hotel Taxes}

Based on Medan City Regional Regulation No. 4 of 2011, the definition of hotel tax is a tax on services provided by hotels. A hotel is a facility for providing lodging / resting services. This includes other related services for a fee, which includes huts, motels, inns, tourism, tourism guesthouses, guesthouses, and the like, as well as boarding houses with more than 10 (ten) rooms. Medan City Regional Regulation No. 4 of 2011 article 2 explains that the objects of Hotel Tax are services provided by hotels with payments, including supporting services as hotel amenities that provide convenience and comfort, including sports and entertainment facilities, where supporting services are telephone, facsimile facilities. , telex, internet, photocopying, washing services, irons, transportation, and other similar facilities provided or managed by the Hotel. Medan City Regional Regulation No. 4 of 2011 Article 7 states hotel entrepreneurs impose hotel taxes on service payments at hotels by imposing a tax rate as the hotel tax rate is set at $10 \%$ (ten percent) and specifically for boarding houses with more than 10 (ten) rooms Those occupied by students with room rental rates above 1 (one) million rupiah per room per month are subject to a tax rate of $10 \%$ (ten percent). 


\section{II.3 Hotel Tax Contribution}

According to the Popular Scientific Dictionary, Dany H. (2006: 264), "Contribution is defined as money donations or favors." Meanwhile, according to the Indonesian General Dictionary, Yandianto (2000: 282) means: "As dues to the association, donations." Starting from the two dictionaries above, it can be concluded that; the contribution is a contribution, support, or support for an activity. So it can be concluded that contributions are donations or support that someone gives to an association, organization, or activity.

Regional Tax Contribution Analysis is an analysis used to find out how much contribution can be contributed from tax revenue to local taxes, then it is compared between the realization of tax revenues against local taxes, while the analysis of the Contribution of Regional Taxes to Local Own Income is an analysis used to determine how much large contributions that can be contributed from Local Taxes to Regional Original Income.

The formula used to calculate contributions is as follows (Handoko, 2013: 3):

Hotel tax contributions $=\frac{\text { Realization of Hotel Tax Revenue }}{\text { Realization of Regional Original Revenue }} \times 100 \%$

Based on the Research and Development Team of the Department of Home Affairs, Faculty of Social and Political Sciences UGM in 1991, the ways to interpret hotel tax contributions are as follows:

Table 2.1 Contribution Criteria

\begin{tabular}{cc}
\hline Contribution rate (\%) & Criteria Contribution \\
\hline$\geq 50 \%$ & Very Good \\
$40,10 \%-50 \%$ & Good \\
$30,10 \%-40 \%$ & Moderate \\
$20,10 \%-30 \%$ & Enough \\
$10,10 \%-20 \%$ & Less \\
$0 \%-10 \%$ & Very less \\
\hline
\end{tabular}

Several studies have been carried out to analyze District / City Original Revenue, which aims for the Regional Government to optimize local taxes to increase PAD, as follows:

a. Tana Toraja Regency Original Revenue by Tonapa et al. (2017) analyzes the effectiveness and contribution of hotel taxes to the Regional Original Revenue of Tana Toraja Regency in 2011-2015. The results show that the local tax collection system has reached a level of $100 \%$ and is effective, but the contribution is still insufficient.

b. Padang City Original Regional Revenue by Yanti and Hadya (2018) analyzes how much the contribution of the tourism sector to the Original Regional Income of Padang City in 2013-2017. The results show that the development of the number of visitors to tourist attractions in Padang city has increased from 2013 to 2017. 
Likewise, the development of tourism object revenue increased significantly in 2016. Meanwhile, the number of SMEs tends to decline until 2017.

\section{RESEARCH METHODOLOGY}

\section{III.1 Types of Research}

This type of research is a case study. According to Sugiyono (2016: 17), research uses the case study method in which researchers conduct in-depth exploration of processes, programs, activities, or events to one or more people. A case bound by time and activity. Researchers collected detailed data using various data collection procedures.

\section{III.2 Types and Sources of Data}

The types of data in this study are as follows: quantitative data in the form of reports in the form of numbers. The data source used in this study is secondary data, namely data on the realization of hotel tax revenue and the realization of regional revenue (PAD) in Medan City from 2016 to 2018.

\section{III.3 Data Collection Techniques}

The data collection technique used in this research is the documentation technique, which is to collect data by taking notes from archives, documents, and reports each year.

\section{III.4 Data Analysis Techniques}

The data analysis technique used in this study is to use descriptive analysis, namely research conducted by collecting data, explaining and analyzing data related to the problems faced, and then drawing conclusions. The way to analyze the data on the contribution of Hotel Tax to Regional Original Revenue (PAD) is by comparing the value of Hotel Tax realization with the Real Local Revenue (PAD) of Medan City and adjusting the value to the criteria set by the Research and Development Team of the Department of Home Affairs, Faculty of Social and Political Sciences UGM in 1991 which is very lacking, less, enough, moderate, good, very good.

\section{FINDING AND DISCUSSION}

Analysis of the Contribution of Hotel Taxes to Local Revenue (PAD) of Medan City

Table 4.1 Realization of Hotel Tax and Local Own Revenue in Medan City

\begin{tabular}{cccc}
\hline Year & Realization of Hotel Tax & $\begin{array}{c}\text { Realization of Local Own } \\
\text { Revenue }\end{array}$ & $\begin{array}{c}\% \\
\text { contribution }\end{array}$ \\
\hline 2016 & 95.882 .427 .290 & 1.535 .309 .574 .015 & 6,24 \\
2017 & 109.115 .442 .280 & 1.739 .756 .922 .634 & 6,27 \\
2018 & 119.664 .695 .854 & 1.636 .204 .514 .684 & 7,31 \\
\hline
\end{tabular}

Based on table 4.1, the results show that the realization of Medan City Hotel Tax continues to increase every year. However, the realization of Regional Original Revenue in Medan City tends to 
fluctuate, wherein 2016-2017 it increased and in 2018 decreased. Meanwhile, the value of the\% contribution increases every year. The following is an analysis of the contribution of the Medan City Hotel Tax each year based on the comparison of the realization of the Hotel Tax with the Regional Original Revenue of the City of Medan:

a. In 2016, the contribution value of the Hotel Tax was at $6.24 \%$. Based on the criteria of the Research and Development Team of the Department of Home Affairs, Faculty of Social and Political Sciences UGM in 1991, the contribution of Hotel Tax to Regional Original Revenue of Medan City is very insufficient.

b. In 2017, the contribution value of the Hotel Tax increased to $6.27 \%$. Based on the criteria of the Research and Development Team of the Department of Home Affairs, Faculty of Social and Political Sciences UGM in 1991, the contribution of Hotel Tax to Regional Original Revenue of Medan City is very insufficient.

c. In 2018 , the contribution value of the Hotel Tax increased by $7.31 \%$. Based on the criteria of the Research and Development Team of the Department of Home Affairs, Faculty of Social and Political Sciences UGM in 1991, the contribution of Hotel Tax to Regional Original Revenue of Medan City is very low.

The contribution of Hotel Tax to Regional Original Income is very insufficient, seen from the $\%$ contribution value of around 6-7\% (less than 10\%). If seen from other sources of Regional Original Income, the largest contribution is local taxes with details of Land Tax. and Rural and Urban Buildings (PBBP2) and Fees for the Acquisition of Land and Building Rights (BPHTB) of around $20 \%$. According to online-pajak.com, the hotel tax calculation rate is subject to $10 \%$ of the amount paid to the Hotel with a hotel tax period of 1 month. Hotel income that is subject to local taxes is room rental, sale of food and beverages, and services provided by the Hotel to guests, for example, laundry services, fitness center services, massage and spa services, and room rental.

\section{CONCLUSION AND FURTHER RESEARCH}

\section{V.1 Conclusion}

Based on the results and discussion of this study, the conclusions obtained are as follows: The Hotel Tax Contribution to the city of Medan increases every year. In contrast to the contribution, the value of the realization of Regional Original Income tends to fluctuate because, in 2016-2017, it increased, while in 2018, the realization value decreased.

\section{V.2 Limitations}

The limitation of this study is the value of the contribution of Hotel Tax to Regional Original Income (PAD) of Medan City is under $10 \%$ and is in the very poor category.

\section{V.3 Suggestions}

Based on the limitations in the research, the suggestion that can be given is for the Regional Government of Medan City to further maximize the potential for hotel tax revenue by collecting hotel tax debt for each taxpayer so that hotel tax revenue can increase significantly following the increase in Regional Original Revenue. 


\section{REFERENCES}

Abdullah, Ikhsan dan Yudhia Ayu Puspita. 2016. Analisis Kontribusi Pajak Hotel Dalam Meningkatkan Pendapatan Asli Daerah (PAD) Kabupaten Deli Serdang. Jurnal Pajak dan Bisnis. Vol. 4 No. 4.

Dani, H. (2006). Kamus Ilmiah Populer. Surabaya: Gita Media Press

Halim, Abdul. 2004. Akuntansi Keuangan Daerah Edisi Revisi. Jakarta: Salemba Empat.

Sugiyono. (2016). Metode Penelitian Kuantitatif, Kualitatif dan R\&D. Bandung: PT Alfabet.

Tim Litbang Depdagri Fisipol UGM Tahun 1991 tentang Kriteria Kontribusi.

Tonapa, Hesty Reny, David Saerang dan Lidia Mawikere. 2017. Analisis Potensi, Efektifitas Dan Kontribusi Pajak Hotel Terhadap Pendapatan Asli Daerah Kabupaten Tana Toraja. Jurnal Riset Akuntansi Going Concern, Vol. 12 No. 1.

Undang-Undang Nomor 33 Tahun 2004 tentang Perimbangan Keuangan Antara Pusat dan Daerah 